Roger Williams University

DOCS@RWU

March 2000

\title{
US government information: selected current issues in public access vs. private competition
}

Susan McMullen

smcmullen@rwu.edu

Follow this and additional works at: https://docs.rwu.edu/librarypub

\section{Recommended Citation}

McMullen, S. (2000). US government information: selected current issues in public access vs. private competition. Retrieved from https://docs.rwu.edu/librarypub/2

This Article is brought to you for free and open access by the University Libraries at DOCS@RWU. It has been accepted for inclusion in Library Faculty Publications by an authorized administrator of DOCS@RWU. For more information, please contact mwu@rwu.edu. 
U.S. Government Information: Selected, Current Issues in Public Access vs. Private Sector Competition

Susan McMullen

Assistant Professor

Information Resources Librarian

Roger Williams University Library

One Old Ferry Road

Bristol, RI 02809

401-254-3086

smcmullen@rwu.edu 
Susan McMullen

Assistant Professor

Information Resources Librarian

Roger Williams University Library

One Old Ferry Road

Bristol, RI 02809

401-254-3086

smcmullen@rwu.edu

\title{
Article Title: U.S. Government Information: Selected, Current Issues in Public Access vs. Private Sector Competition
}

\begin{abstract}
:
Web information systems are having a profound effect on the way information is being disseminated today. Current technological advances have caused many government agencies to reevaluate their practice of contracting with private sector vendors who have traditionally repackaged and marketed the agency's raw data. These new opportunities for government agencies wishing to make information publicly accessible have blurred the traditional distinctions between public and private dissemination activities. Low-cost public dissemination of information has resulted in private sector vendors arguing that public electronic distribution and publication creates unfair competition. New partnerships, such as the recent venture between the NTIS and the commercial search engine, Northern Light, in developing the "usgovsearch" product are also being explored. From another viewpoint, library associations are strongly supporting legislation that would broaden, strengthen, and enhance public access to electronic government information. Key issues to be discussed: 1) the debate concerning public versus private access to government information; 2) Does electronic access to government information eliminate the need for printed documents? 3) Joint efforts - when should the government team up with private sector allies to charge for information services and access?
\end{abstract}

Keywords:

government information, public access, public/private partnerships, electronic documents, government publishing

\section{Author Biography:}

Susan McMullen is Assistant Professor/Information Resources Librarian at Roger Williams University Library in Bristol Rhode Island. Her interest in public access to government information has evolved through 22 years of public service librarianship in both public and academic libraries. Currently, she is responsible for coordinating the library's bibliographic instruction program, providing reference assistance and developing the university's library web site. Recent publications include co-authorship of an article that appeared in the volume 27, number 2, 1999 issue of References Services Review entitled "What Does Electronic Full-text Really Mean? A Comparison of Database Vendors and What They Deliver" and web reviews written for Electronic Resources Review, volume 3, numbers 2 and 9. 


\section{U.S. Government Information: Selected Current Issues in Public Access versus Private Competition}

\section{Introduction}

The U.S. federal government is one of the largest producers of information in the world. By law, government information resides in the public domain [1]. For years, private sector publishers have been repackaging and reselling non-copyrighted government works for a profit, primarily because the government has been unable to meet market demands for making its information available in a timely and efficient manner. Today's technologies have created new opportunities for government agencies wishing to make their information publicly accessible and have blurred the traditional distinctions between public and private dissemination activities. This low-cost public dissemination of information has encouraged private sector vendors to argue that public electronic distribution and publication creates unfair competition. They argue that the government could eventually become the only supplier of government information. How can the private sector continue to make a profit when the same information is available for free?

Though some government agencies are able to disseminate the information contained within their databases quickly, others are overwhelmed by the newly created expectations for the quick distribution of government information. Can timely and costefficient dissemination be made within the constraints of existing budgets and staff? In meeting its responsibility to the taxpayers funding federal research and publications, how can government best make these resources available to scholars, industry, and the 
general public? In an effort to meet public demand, independent federal agencies are exploring a variety of options for distributing their information, including contracting with private vendors, eliminating the printing of documents, and bypassing the GPO as a centralized source for disseminating government information. The perspective of this article is from that of a librarian who has concerns for the continued permanent public access to government information. Key issues to be discussed include: 1) the debate concerning public versus private access to government information; 2) electronic access to government information and any future need for printed documents; 3 ) and possible joint efforts of government and private sector allies to charge for information services and access.

\section{Background}

Under the provisions outlined in Title 44 of the United States Code, "Public Printing and Documents," the U.S. government has historically collected, generated, and disseminated information to its citizens. Taxpayers fund the agencies responsible for publishing these materials, so it follows that citizens should have public access to this information at little or no cost. The Freedom of Information Act (FOIA) of 1966 [2] guaranteed public access to government records unless the information fell under one of nine exemptions that protect government security and personal privacy. The availability of electronic publishing and dissemination raised public expectations for gaining immediate access to government reports and in 1996, the FOIA was updated. The Electronic Freedom of Information Act mandated that the "public have timely and meaningful access to information" [3] Additionally, the Clinton administration's passage of the Paperwork Reduction Act (PRA) in 1995 [4] also placed new demands 
on government agencies to provide electronic public access to all of their documents.

Not only did the PRA seek to minimize paperwork burdens and ensure broader and more timely electronic dissemination of public information, it "prohibited some copyright-like devices that agencies used to control information" [5].

With respect to information dissemination, each agency shall not, except where specifically authorized by statute--a) establish an exclusive, restricted, or other distribution arrangement that interferes with timely and equitable availability of public information to the public; b) restrict or regulate the use, resale, or redissemination of public information by the public; c) charge fees or royalties for resale or redissemination of public information; or d) establish user fees for public information that exceed the cost of dissemination [6].

As is apparent from the legislation of the last decade, government agencies are statutorily mandated to make their research and publications publicly available. However, there is no centralized information policy that defines how federal agencies should electronically publish, disseminate, and ensure permanent access to their documents. Because of the vague nature of Title 44, librarians and government information users are concerned that access to government resources is eroding.

On February 27, 1997, Senator John Warner articiulated his concern about "The Growing Crisis in Public Access to Public Information." (143 Congressional Record S1730). Increasingly, federal agencies are circumventing their obligations under Title 44. The trends toward decentralization, privatization, and commercialization of government information and the increased use of electronic technologies to produce and disseminate information have lead to a large amount of government information eluding the primary systems of public access. The result is increased "fugitive" information and reduced public access [7].

Electronic availability to documents can only increase public access if government information can be systematically located and if some way of permanently archiving this information can be achieved. On July 10,1998, Senators John Warner and Wendell Ford jointly introduced S. 2288, The Wendell H. Ford Government Publications Reform 
Act of 1998. This bill included provisions to revise Chapter 19 of Title 44, the law governing public access to government publications and the Federal Depository Library Program. The intent of this legislation was to amend Title 44 to improve and to enhance public access to government information [8]. Though this bill received strong endorsement from the library community, it was opposed by business. In opposition, the U.S. Chamber of Commerce stated that the "legislation runs counter to the longstanding desire of the U.S. Chamber of Commerce to move commercial activities of the government to the private sector where they can be performed more efficiently and at lower cost to the taxpayer" [9]. The Chamber and other members of the private sector stated that the legislation was intended to create a government printing monopoly. The $105^{\text {th }}$ Congress did not pass the proposed reforms outlined in S. 2288.

In 1999 library associations called for revisions to Title 44, Chapter 41 of the U.S. Code, "Access to Federal Electronic Information". The current proposed legislation, "Next Generation Electronic Government Information Act of 1999" would: broaden, strengthen, and enhance public access to electronic government information and provide permanent public access to and ensure authenticity of electronic government information. [10]. The proposed bill is very specific about the role of the Superintendent of Documents in ensuring permanent public access to government resources. The proposed change to section 4104 is clear in its intent to ensure public access through the Superintendent before any government agency can sell its information or contract exclusively for creation, storage, reproduction or dissemination of its electronic government information products [11]. 
The current availability of electronic government information has raised many questions regarding its access. In its 1995 white paper, Government Information in the Electronic Environment, the American Library Association's Government Documents Round Table (GODORT) identified many of the issues involved. These issues have yet to be resolved. Key concerns relevant to this paper are the following. To what extent should government provide free information, rather than placing it on a cost recovery basis? Because of government downsizing, to what extent will government depend on the private sector for software development to access its raw data? Who should be responsible for disseminating government information on the Internet? - numerous models exist including partnerships with government agencies and universities and commercial vendors. While electronic distribution is often a cost-saving measure for the information producer, who will bear the costs for hardware, software, connectivity, staff training and paper for printing? [12]

\section{- The debate concerning public versus private access to government information}

In order to facilitate quicker access to government publications and to relieve themselves from this burdensome activity, many agencies have contracted with private vendors who repackage, sometimes add value to, and sell aging publications or access to databases of government information to the public for a profit. This is referred to as privatization. Many believe this practice has resulted in a loss of government information in the public domain. In his statement Before the House Subcommittee on Government Management, Information and Technology Committee on Government 
Reform and Oversight on the Government Printing Office and Executive Branch

Information Dissemination, Robert Oakley spoke about the effects of privatization.

Librarians and users alike are increasingly frustrated by the steady removal of important government resources from the public domain. The information needs of the American public are not served when agencies contract with private publishers and fail to supply these resources to the Superintendent of Documents for distribution to depository libraries. Broad access and use of publicly-funded information are substantially impaired when licensing agreements prevent or curtail redissemination, or when agencies copyright or restrict distribution of information [13].

Federal agencies have frequently responded that the practice of privatization is not only beneficial to the private information industry, which is free to re-market and re-sell government information, but it also provides government agencies with additional financial support. Both the Securities and Exchange Commission and the U.S. Patent and Trademark Office initially resisted demands for providing free access to their raw data because they believed that making it available for wholesale downloading would jeopardize their agency's existence.

Carl Malumud tested this theory. In 1993, with a grant from the National Science Foundation, his company, Internet Multicasting Service, began buying the raw financial data from the Securities and Exchange Commission and distributing it free over the Internet [14]. After surviving 18 months of Malumud's free distribution service, the SEC agreed to take over and provide the financial data itself. Contrary to the SEC's initial resistance, this free access did not have an adverse effect on the agency's ability to fund itself. Private vendors can still remain competitive by enhancing government products to offer added services such as data analyses, alert mechanisms and document 
delivery. By adding proprietary information to basic EDGAR data, vendors can create new and improved products that are easily marketed for business and commercial use.

EDGAR on the Internet clearly demonstrates the capacity of the Internet to effectively disseminate government information in a timely and inexpensive way. As tools for WIS development and the infrastructure for data dissemination improve, government-owned Web systems will satisfy the basic needs of the public for access to key government information. As WIS capabilities increase, data vendors will have to migrate value from simple value addition mechanisms that leverage the features of technology to competitive models which leverage intelligence applied to select aggregate bundles of data, customized to individual users and communities. These transformations will enhance customer value and create new markets for information vendors [15].

Privatization raises many issues of concern among advocates who believe there should be free access to government information. Public access groups wish to ensure wide distribution of government databases that have been created at the taxpayers expense. Private vendors, whose livelihoods depend on making a profit through the publishing and distribution of information, commonly charge prices that some individuals believe to be exorbitant to access the contents of their databases and publications. This is the free market economy at work when information comes from private sources. However, when the information private sector vendors are selling at a profit is obtained from government agencies, many maintain that citizens are being asked to pay for access to documents that they have already paid to research and publish. "Although, the government often contracts with private vendors, publishers, and software developers to provide added value to information databases, this process should never be one which prohibits free access to government information" [16]. 
Much has changed in the past couple of years as today's current technological advances have encouraged many government agencies to re-evaluate their need to contract with private vendors in order to repackage and sell their raw data. Web information systems have greatly enhanced the government's ability to disseminate information already contained in its databases. "The rise of the Internet as a ubiquitous channel for distributing information cheaply is adding new pressures from public information advocates who contend that the expense needed to make government data available to its citizens has fallen significantly" [17]. The Electronic Freedom of Information Act, the distribution capabilities of the Web, and the public demand for immediate access to government information have all contributed to the development of government-supported databases that are now freely available to search. This trend is likely to continue in the future. EDGAR, Agricola, Medline, ERIC, PubScience, Supreme Court Cases, and the Federal Register are among the most notable government databases available for free public access.

This author believes that free access to these databases should be available to the public. It is with the support of taxpayer dollars that government agencies, such as the National Library of Medicine and the Department of Education, have produced and continued to maintain their vast databases over the years. Publishers of journals indexed in these databases have also benefited by having greater visibility to their articles retrieved by searching the databases. These public databases offer publishers the opportunity to sell their journals and articles directly to consumers. For example, PubMed offers links to the Web sites of participating publishers, who may require users to subscribe before they are able to view the full-text [18]. 
The non-copyrighted information contained in Medline, ERIC, Agricola, etc. has been available to vendors for years. They are still able to market their versions of the databases by adding value through search, display, and delivery features. In addition to these value-added features, private sector vendors can offer better customer service, more aggressive marketing for their products, better quality control, more reliable and complete access to government documents, and "alternative versions of similar products to satisfy limited markets"[19]. As the public has greater access to information there will be new markets created for sophisticated products that can control, manipulate, and make sense of it [20].

The latest development concerning the partnering of the National Technical Information Service and the privately owned search engine, Northern Light, adds a new twist to the debate over private vs. public access to information. Instead of a government entity making distribution of the information contained within its database freely accessible, the NTIS contracted with a private sector vendor to produce a feebased product. Furthermore, the Secretary of Commerce has announced the closing of the National Technical Information Service (http://www.ntis.gov). Advocates for rights to public information were quick to rally and the Clinton administration opposed the notion of paying for government information. In response to the public outcry, Northern Light agreed to provide free access to a portion of its government database to public libraries and schools. Initially, free access for public libraries did not allow for free access to the NTIS database. However, at this writing, Northern Light is re-evaluating its pricing structure. Currently, searching the entire "usgovsearch" database, including the NTIS archives, is free. However, in order to view NTIS abstracts, the user must pay 
a dollar for each summary. It is important to understand that "usgovsearch" is a commercial venture that is not "owned" or funded by the government or with tax dollars. Renee Edwards, public affairs director for NTIS states that the agency will only receive revenue from the sale of NTIS documents through the "usgovsearch" service, not for the subscription service. Edwards noted that "Northern Light is another reseller for the NTIS, like Dialog and other online services, and NTIS hopes to increase the sale of its documents through a service that makes it easy for the public to find what they need" [21]. "Usgovsearch" is a value added service that provides enhanced search capabilities for finding government documents.

If the NTIS does close, it has been proposed that its 3 million publications be shipped to the Library of Congress for cataloging, indexing, and archiving. It is the hope of the library community that the government will make access to these documents available for free on the web. At the Senate hearing on the proposed closing of the NTIS, Michael DiMario, Public Printer of the GPO, testified that "the Government Printing Office would be the logical place for all NTIS functions because of its similar collection, maintenance, and dissemination functions. He emphasized that having NTIS materials available through the Federal Depository Library Program (FDLP) would help advance public access to government information and bring major resolution to fugitive document problems" [22].

As long as the public is given some means of free access, it appears that the "usgovsearch" product as a commercial venture will offer a valuable, time efficient means for accessing a wide range of government materials for those who want to pay for the convenience of using it. 
- Does electronic access to government information eliminate the need for printed documents?

Electronic access presents both new opportunities and new challenges. The intent of recent legislation, such as the Paperwork Reduction Act of 1995 [23] and the Electronic Freedom of Information Act of 1996 [24], was to make government information more timely and accessible. Web tracking statistics from federal agencies and from the GPO indicate a steady increase in the use of online documents over the past few years. "Recent statistics indicate that GPO Access fulfills approximately 21 million document retrievals per month- with a total of more than 228 million retrievals during fiscal year 1999 alone"[25]. Many believe that as the Internet continues to become more mainstream in American homes and businesses, the electronic format will make the need for printing documents obsolete.

It appears that many in Congress already believe that electronic documents can replace their printed counterparts. In May 2000, the House Appropriations Committee in its Legislative Branch Appropriations Bill, 2001 attempted to effectively eliminate printed materials from the FDLP by making drastic budget cuts to the GPO/FDLP program. The House committee recommended cutting the depository library program from this fiscal year's $\$ 29.9$ million to $\$ 11.6$ million for fiscal year 2001 . The bill did not fund printing requests for the United States Code, the Congressional Directory and other existing government publications [26]. In an ensuing grassroots efforts, librarians were encouraged to "demonstrate to officials that library users are not and cannot use electronic information to the exclusion of printed and tangible documents " [27]. 
The question of whether or not web access eliminates the need to produce duplicate print copies of documents, is currently being evaluated by educational institutions, organizations, industry, and government. The most pressing concern is how to utilize new technologies to ensure permanent public access. If print is to be eliminated, archivists and records managers must devise a systematic way to identify electronic documents that are necessary for preservation and make them accessible for generations to come. Many archivists and librarians are worried that without a centralized information retention policy, important raw materials are being deleted from information systems.

Library associations also want to ensure that older documents that are needed for a variety of citizen needs and research purposes do not fall through the cracks. As newer versions of works are posted to web sites, who has the responsibility for ensuring that older versions remain accessible and are not deleted from computer files? The InterAssociation Working Group on Government Information Policy (IAWG) recently posted to their web site a list of 70 electronic government publications that were previously accessible via the Internet but are no longer available.

No provision has been made to ensure that the information contained in these publications will continue to be available to current and future users. Users who relied on or used these electronic publications no longer can refer to them, and no information is provided to explain why the publication no longer exists. Future researchers will not be able to identify and access these publications for historical or other purpose [28].

The key findings from the Report on the Assessment of Electronic Government Information Products by the U.S. National Commission on Libraries and Information Science (NCLIS) also indicate that there is an overall lack of information policy 
guiding electronic publishing and dissemination, that the responsibility for electronic publishing is decentralized, diffuse, and unclear, and that the concept of permanent public access is not well understood [29].

These concerns are being brought forward in proposed legislation, the Next Generation Electronic Government Information Access Act of 1999 [30], which seeks to revise Chapter 41 of Title 44 to ensure permanent public access through the Federal Library Depository Program. Another area of concern this bill addresses is the need to ensure the authenticity of electronic government information. Users must be assured that the information located on federal web sites is, indeed, official.

With careful planning and adequate legislation it seems inevitable that electronic access will eventually replace storing documents in print format. However, the public's preference for printed copies of lengthy documents and books will probably not disappear. Technologies supporting Books-On Demand services offer new ways of supplying printed copies on a per need basis. In any case, information systems of the future must assure the readability of electronic files created by today's computerized systems.

- Joint efforts - when should the government team up with private sector allies to charge for information services and access?

Though public access advocates strive to ensure that there will continue to be free access to government information, there exists an awareness that the government has not always been successful in delivering access to its publications in a timely and efficient manner. The downsizing of federal government agencies has contributed to this problem, causing many agencies to streamline their functions and partner with 
commercial vendors who can more expediently meet the demand for quick access to federal information. Additionally, private sector vendors can provide many value-added features that make locating government information easier and more efficient. Though commercial vendors pass on charges to the consumers of their databases, taxpayers are not charged for the creation of these services. Should taxpayers invest more tax dollars to make information more freely accessible when many of them will have no interest in the information provided?

The basis for charging for services generated by private-public partnerships should be in the value-added features that commercial vendors use to create a more convenient way to access government information resources. In these cases, charges should be passed on to the consumer for commercial services provided. Business and industry require greater access to a broader range of government publications and are willing to pay for enhanced search services.

In the mid 1990's, the federal government began an effort to supplement agency and private sector initiatives for finding government information by establishing an agencybased Government Information Locator Service (GILS). The role of the GILS is "to help the public locate and gain access to public information within agency inventories [31]." The decentralized framework for the GILS offered a standardized mechanism for agencies to fulfill their federally mandated requirements for making their records publicly accessible [32]. Though the GILS has provided a foundation for managing federal government information, not all agencies have allocated the resources and staff to participate. Therefore, the GILS is not considered to be a comprehensive database for locating government-wide information at this time [33]. 
Although the public should be guaranteed free access to government documents through the Government Information Locator Service (GILS), agency web sites, and the FDLP, there are circumstances when private-public partnering presents solutions when government funding is unavailable. The proposed closing of the NTIS has raised new questions about whether or not a service of this type should be required to be selfsupporting [34]. Can the services provided by the NTIS be successfully transferred to another government agency? Will federal agencies eventually have to pay private vendors to search the information contained in government databases? The partnering of NTIS and Northern Light may have offered one alternative. However, since Northern Light is currently re-evaluating its pricing structure for "usgovsearch," it is unclear how the product will continue to be marketed. Initially, free access to public and FDLP libraries was provided for searching the vast amount of information found on government web sites, but for more comprehensive access to the NTIS database, a modest charge was imposed. Today, access to the NTIS database on "usgovsearch" is free.

Issues related to public-private partnering are likely to increase in the future as the government seeks new ways to disseminate its information effectively without increasing the cost of doing so. Technology is making it possible for government agencies to provide new services to the public, though it is yet to be determined if new services can continue without creating allies from the private sector and charging for the additional services provided. In 1999, National Institutes of Health director, Harold Varmus, announced a proposal to create a free Internet archive of biological and medical papers. "The goal is to make new research freely available to scholars around 
the world" [35]. Yet, the database, called PubMed Central, has met with mixed reviews. Though, its intention is to further the collaborative nature of scientific study and make current research readily available, independent publishers were concerned that it's original intent of making unreviewed articles available for public distribution would undermine the peer-review process. In response to these concerns, PubMed Central will only make journal content available after its publication.

The issue of whether or not scientific publishing of government funded research belongs with commercial publishers has been periodically questioned and challenged throughout the last century. In his article, "The Republic of Federal Scientific Publication: The Not So Public Domain," John Spencer Walters provides an excellent history of the federal government's practice of contracting with independent publishers to distribute government funded research. At the conclusion of World War II, it was determined by the Office of Scientific Research and Development (OSRD) that "private publishers, as opposed to the government, afforded the most economical method of publication, and that they effected the most widespread distribution" [36]. This practice has continued throughout the twentieth century as government agencies and private contractors perpetuated an "irreversible publishing paradigm" [37]. The contractual system remained virtually unchallenged as advocates for privatizing government functions predominated over efforts by Senators Russell Long, Hubert Humphrey, and others to make government funded research publicly available [38].

This new database initiative, PubMed Central, implements a fundamental change in scientific publishing, offering scientists and libraries new opportunities for accessing current medical and scientific research. However, many have still expressed concerns 
about the cost of such a database to the taxpayer and whether or not the NIH can continue funding for the project. Librarians have also raised concerns about governance and archiving [39]. It appears that compromise solutions are being sought to make this type of publicly accessible database viable. Even a low cost option to defray the cost of maintaining the database would be an acceptable alternative to the current high cost of obtaining access to scientific research in journals.

\section{Conclusion}

As illustrated by the examination of these selected issues, the proliferation of Web information systems is having a profound impact on how government information is being disseminated. The web is offering both new opportunities for timely and efficient access to information contained in federal databases while at the same time raising questions regarding the continuation of free public access to that information. Practices of decentralization, privatization, and commercialization may be eroding the programs that have traditionally ensured free public access. Currently, there is no centralized information policy in place for determining how federal agencies should publish, disseminate, and ensure permanent access to their documents. Librarians, concerned that the convenience and fascination with web publishing will undermine their past efforts and the Federal Depository Library Program, have proposed legislation that would enhance and strengthen public access to government information and ensure permanent access to electronic government information. Recently, concerns have been further exacerbated by the proposal to close the NTIS and the House Appropriations Committee's call for budget cuts to the GPO/FDLP that would effectively eliminate 
GPO publishing of printed materials. Elimination of tangible government resources without a clear and systematic policy for electronic preservation and retention could greatly increase the number of fugitive federal documents and result in the deletion of important unique materials from computer systems. In addition to lobbying for new legislation that will update Title 44 of the U.S. Code, librarians need to work closely with government agencies to set new standards for electronic preservation. Otherwise, permanent loss of information will most likely be consequential.

Increased public access to the information contained in government databases, such as PubMed, is likely to continue and grow. Though private vendors argue that the government is creating an unfair monopoly, this new competition may force private vendors to create value-added products that will enhance the information consumer's ability to digest, analyze, and manipulate government information more efficiently and meaningfully. In other efforts, libraries will want to become involved in new partnerships between private and public sectors that may offer low-cost alternatives to the escalating costs of traditional journal sources. While, it is difficult to predict how the web will continue to change the nature of government dissemination of information, it is clear that persistent oversight and careful planning by government agencies and library organizations will be necessary to ensure continued permanent public access to government information. 


\section{NOTES}

1. "Subject Matter of Copyright: United States Government Works," Title 17 U.S. Code, sec. 105. See also "An Act for the General Revision of the Copyright Law. Title 17 of the United States Code, and for Other Purposes" (PL 94-553, 19 October 1976), 90 United States Statutes at Large, 2541-2590.

2. "Freedom of Information Act," Title 5 U.S. Code, sec. 552.

3. "Electronic Freedom of Information Act Amendments of 1996" (PL 104-231, 2 October 1996) 110 United States Statutes at Large, 3048-3054.

4. "Paperwork Reduction Act of 1995" (PL 104-13, 22 May 1995) 109 United States Statutes at Large, 163-185.

5. Robert Gellman, "The America Model of Access to and Dissemination of Public Information" (paper presented at the Access to Public Information: A Key to Commercial Growth and Electronic Democracy Conference, Stockholm, Sweden, 27-28 June 1996), $<$ http://www2.echo.lu/legal/stockholm/en/gellman.html>, (accessed November 1999).

6. “Federal agency responsibilities," Title 44 U.S. Code, Chapter 35, sec. 3506(d)(4).

7. Robert L. Oakely, Government Reform and Oversight on the Government Printing Office and Executive Branch Information Dissemination, statement before the House Subcommittee on Government Management, Information and Technology, $105^{\text {th }}$ Cong. $1^{\text {st }}$ sess., 8 May 1997. In his statement Oakley makes reference to Senator John Warner of Virginia speaking on "The Growing Crisis in Public Access to Public Information" $105^{\text {th }}$ Cong., $1^{\text {st }}$ sess.

Congressional Record 143, no. 23, daily ed. (27 February 1997), S1730. The text of Oakley's statement is available at the web site for American Association of Law Libraries Washington Affairs Online, <http://www.ll.georgetown.edu/aalllwash.tm059701.html>, (accessed June 2000).

8. Wendell H. Ford Government Publications Reform Act of $1998,105^{\text {th }}$ Cong., $2^{\text {nd }}$ sess., S. 2288, Congressional Record, 144, no. 91, daily ed. (10 July 1998), S7953-7955. This did not pass during the $105^{\text {th }}$ Congress and has expired.

9. U.S. Chamber of Commerce, "Oppose S. 2288, the Federal Publications Dissemination Act, in its current form," (October 2, 1998), <http://www.uschamber.org/policy/8newmarkets/issues/736/lc981002.htm>, (accessed June 2000).

10. American Library Association, "The Next Generation Electronic Government Information Act of 1999," (Discussion Draft, April 8, 1999). This is the text for proposed legislation supported by the American Library Association, $<$ http://www.lib.berkeley.edu/GODORT/9907bill.pdf $>$, (accessed June 2000).

11. Ibid. 
12. Ad Hoc Committee on the Internet, Government Documents Roundtable (GODORT), White Paper -- Government Information in the Electronic Environment, (January 1996), $<$ http://www.lib.berkeley.edu/GODORT/whiteppr.html $>$, (accessed November 1999).

\section{Oakley.}

14. Robert Thomasen, "Battle Brews Over Fees for SEC Report; Group Believes Public Should have Free Access," Washington Post, 9 January 1995, final edition, p. F17.

15. Ajit Kambil and Mark Ginsburg, "Public Access Web Information Systems: Lessons from the Internet EDGAR Project," Association for Computing Machinery, Communications of the $A C M$ 41, no.7 (July 1998): 97.

16. Ad Hoc Committee on the Internet, Government Documents Roundtable (GODORT).

17. John Markoff, "Internet Gadfly Wants U.S. to Put more Complete Databases Online: If the Government won't do it, he has Guerilla Plan," Star Tribune, 10 May 1998, metro edition, p. $6 \mathrm{D}$.

18. United States National Library of Medline, "Fact Sheet: Medline Retrieval on the Web," (18

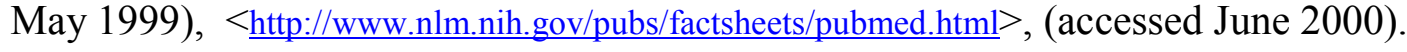

19. Hilary Caws-Elwitt, "Copyright, Competition, and Reselling of Government Information: Impact on Dissemination," Katherine Sharp Review no. 7 (Summer 1998), $<$ http://www.lis.uiuc.edu/review/7/caws-elwitt.html $>$, (accessed December 1999).

20. Ibid.

21. Paula Hane, "Northern Light Technology's Usgovsearch Begins Commercial Operation with Revised Pricing Plan," Information Today 16, no. 7 (July/August 1999): 22.

22. "September 14 House Hearing on Commerce Department Plans to Close NTIS," American Library Association Washington Office Newsline 8, no. 90 (16 September 1999), $<$ http://www.ala.org/washoff/alawon/alwn8090.html>, (accessed June 2000).

23. "Paperwork Reduction Act of 1995" (PL 104-13, 22 May 1995) 109 United States Statutes at Large, 163-185.

24. "Electronic Freedom of Information Act Amendments of 1996" (PL 104-231, 2 October 1996) 110 United States Statutes at Large, 3048-3054.

25. U.S. Government Printing Office, Biennial Report to Congress on the Status of GPO Access, (31 December 1999). See Executive Summary and Appendix C-GPO Access Statistics. $<$ http://www.access.gpo.gov/su_docs/aces/biennial/index.html>, (accessed June 2000). 
26. U.S. Congress, House, Committee on Appropriations, Making appropriations for the Legislative Branch for the fiscal year ending September 30, 2001, and for other purposes, $106^{\text {th }}$ Cong., $2^{\text {nd }}$ sess., 2000, H.R. 4516, House Report 106-635. Bill text and committee report available by searching Thomas, $<$ http://thomas.loc.gov $>$, (accessed June 2000).

27. "No Final GPO Appropriations as Congress Takes Memorial Day Recess," American Library Association Washington Office Newsline 9, no. 49 (26 May 2000), $<$ http://www.ala.org/washoff/alawon/alwn9049.html $>$, (accessed June 2000).

28. Inter-Association Working Group on Government Policy (IAWG), "Electronic Information No Longer Available on the Internet," (4 August 1998),

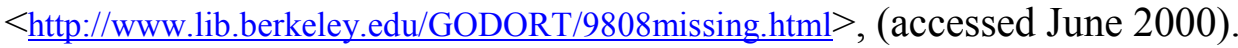

29. Government Printing Office and National Commission on Libraries and Information Science (NCLIS), Report on the Assessment of Electronic Government Information Products, (30 March 1999), Commissioned by the GPO and prepared by Westat, Inc. under a contract from NCLIS. $<$ http://www.access.gpo.gov/su docs/nclisassessment/report.html $>$, (accessed June 2000).

30. American Library Association.

31. Eliot J. Christian, "Helping the Public Find Information: The U.S. Government Information Locator Service (GILS)," Journal of Government Information 21, no. 4 (July/August 1994): 306.

32. Margaret O'Neil Adams and Sharon Gibbs Thibodeau, "The Government Information Locator Service: Origins and Potential," Journal of Government Information 23, no. 4 (July/August 1996): 457.

33. GPO Access User Access Support Team "What is GILS," (16 November 1999), $<$ http://www.access.gpo.gov/su_docs/gils/whatgils.html $>$, (accessed June 2000). See also William E. Moen and Charles R. McClure, "An Evaluation of the Federal Government's Implementation of the Government Information Locator Service (GILS): Final Report," (30 June 1997), (ERIC Document ED 410965). Also available electronically at $<$ http://www.access.gpo.gov/su_docs/gils/gils-eval/html/toc.html $>$.

34. Caroline C. Long, Testimony on the Proposed Closing of the National Technical Information Service, statement before the Subcommittee on Technology, U.S. House Science Committee, $106^{\text {th }}$ Cong. ${ }^{\text {st }}$ sess., (14 September 1999), < http://www.arl.org/info/frn/gov/long.html $>$, (accessed June 2000).

35. Lance Sultzbaugh, "The New Scientific Publishing Wars," The Chronicle of Higher Education 46, no. 4 (17 September 1999): A72. 
36. John Spencer Walters, "The Republic of Federal Scientific Publishing: The Not-So-Public Domain," Journal of Government Information 25, no. 4 (8 July 1998): 335.

37. Walters, 334.

38. Walters, 341, 344-345.

39. Marianne Burke, "PubMed Central: Be Careful What You Ask For," College \& Research Library News 61, no.1 (January 2000): 22. 